This is a post-print version of:

Barilli E, González-Bernal MJ, Cimmino A, Agudo-Jurado FJ, Masi M, Rubiales D \& Evidente A, 2019. Impact of fungal and plant metabolites application on early development stages of pea powdery mildew.

Printed version can be visited at:

Pest Management Science 75(9): 2464-2473,

doi: 10.1002/ps.5351. 


\section{Impact of fungal and plant metabolites application on early development stages of pea powdery mildew}

Eleonora Barillii ${ }^{a, \text { }, *}$, María J. González-Bernal ${ }^{a, \S}$, Alessio Cimmino ${ }^{\mathrm{b}}$, Francisco J. Agudo-Jurado ${ }^{\mathrm{a}}$, Marco Masi $^{\mathrm{b}}$, Diego Rubiales ${ }^{\mathrm{a}}$, and Antonio Evidente ${ }^{\mathrm{b}, *}$

${ }^{\mathrm{a}}$ Institute for Sustainable Agriculture, CSIC, 14004 Córdoba, Spain

${ }^{\mathrm{b}}$ Dipartimento di Scienze Chimiche, Università di Napoli Federico II, Complesso Universitario Monte Sant'Angelo, Via Cintia 4, 80126 Napoli, Italy

${ }^{\S}$ Authors equally contributed to the study

*Correspondence to: Antonio Evidente, Dipartimento di Scienze Chimiche, Università di Napoli Federico

II, Complesso Universitario Monte Sant'Angelo, Via Cintia 4, 80126 Napoli, Italy; Phone: +39 081 2539178. Fax: +39 081 674330; Co-corresponding author: Eleonora Barilli.

E-mail: evidente@unina.it 


\begin{abstract}
BACKGROUND: Pea powdery mildew incited by Erysiphe pisi represents a major constraint for pea crop worldwide. Crop protection is largely based on chemical control, although recently a renewed interest in the discovery of natural products as alternative to synthetic fungicides application has emerged. Thus, twelve bioactive plant and fungal metabolites belonging to different class of natural compounds were evaluated, together with a commercial fungicide, at different concentrations on detached pea leaves for their potential to inhibit spore germination and subsequent stages of fungal growth. Then, the most effective metabolites were also tested at different concentrations "in planta" under controlled conditions, in order to evaluate the level of control achieved by treatments before, concurrently and after pathogen inoculation. Pathogen development was macroscopically scored on whole plants as percentage of disease severity and area under the disease progress curve (AUDPC).
\end{abstract}

RESULTS: Cavoxin, inuloxin C and sphaeropsidin A strongly inhibited E. pisi germination and haustoria formation and reduced colony size. This effect was dose dependent. These results were further confirmed in whole plants by spraying the metabolites on plant leaves for preventive or curative control, which reduced fungal developmental of E. pisi at levels comparable with those obtained by application of the fungicide.

CONCLUSIONS: Cavoxin, inuloxin $\mathrm{C}$ and sphaeropsidin A have potential as alternatives to synthetic fungicides for the control of crop pathogens of economic importance such as powdery mildew.

KEYWORDS: Erysiphe pisi; Pisum sativum; biocontrol; fungal and plant metabolites

RUNNING TITLE: Plant and fungal metabolites for pea powdery mildew biocontrol 


\section{INTRODUCTION}

Pea (Pisum sativum L.) is one of the important grain legume crops worldwide mainly used for consumption as green vegetables and dry seeds. ${ }^{1}$ Pea is cultivated in 7.3 million hectares with a total production of 600 metric tons per year globally. ${ }^{2}$ Productivity of pea is affected by many diseases and insect-pests. Among the various diseases affecting pea, powdery mildew, caused by Erysiphe pisi, is of great significance. ${ }^{3}$ The biological cycle of $E$. pisi includes germination of conidia (asexual spores) or ascospores (sexual spores) on host epidermis and direct penetration of epidermal cells by invagination of haustoria into epidermal cells for feeding, followed by subsequent epiphytic colony growth. ${ }^{4}$ Erysiphe species are obligate parasites feeding on alive plant cells, that cannot be cultured on artificial nutrient medias. Therefore bioassays for these pathogens are very complicated.

Owing to their economic importance, a large number of methods to control powdery mildew have been proposed, including cultural practices, the use of resistant varieties and fungicide application. Despite the substantial effort to generate resistant pea varieties, the use of synthetic chemical fungicides is the mainstay method for E. pisi control. ${ }^{5}$ However, their widespread application has caused many environmental concerns due to low specificity and slow biodegradability. These include pollution of soil and groundwater, negative impact on flora and fauna and risks to human and animal health. Furthermore, the high application costs and the ability of the pathogen to evolve resistance to chemical fungicides have prompted efforts to discover natural products as templates for development of fungicidal biochemicals with new molecular structures and mode of actions. Many plant pathogens, especially necrotrophic or hemibiotrophic fungi, produce novel antimicrobial compounds that can be a source of such useful metabolites. ${ }^{6,7,8}$ Similarly, active metabolites isolated from weeds and cultivated plants have a number of potentially useful biological activities. ${ }^{9,10}$ As spore germination, haustoria formation and subsequent colony growth are key phases for the initial development of biotrophic plant pathogens such as powdery mildews, an approach for their management could be the use of natural plant or fungal metabolites as inhibitors in these early stages of infection. 
In this manuscript the potential of ten fungal and two plant toxins was tested as natural fungicides assaying their inhibitory effects on early stages of development of E. pisi in detached leaf bioassays. The three most effective metabolites were also tested in whole plants at several application times to determine their protective and/or curative effects against powdery mildew.

\section{MATERIAL AND METHODS}

\subsection{Plant and fungal bioactive metabolites}

The phytotoxins used for the study (Fig. 1A; 1B, Table 1) belong to different classes of natural compounds, as follow: the sesquiterpenes inuloxins $A$ and inuloxin $C$, and $\alpha$-costic acid (1-3, Fig. 1A) were purified from the organic extract of Inula viscosa (L.) Ait. ${ }^{10}$ The diterpenes sphaeropsidin A and sphaeropsidin C (4 and 5, Fig. 1B) and cyclopaldic acid (6) were purified from the culture filtrates of Diplodia cupressi A.J.L. Phillips \& A. Alves ${ }^{11,12}$ and Seiridium cupressi (Guba) Boesewinkel, ${ }^{13}$ respectively. Cavoxin (7) was isolated from the liquid culture of Phoma cava Schulzer, ${ }^{14}$ while epi-epoformin, $(\mathbf{8})$ was purified from the organic extract of Diplodia quercivora Linaldeddu \& A.J.L. Phillips. ${ }^{15}$ Cytochalasins A (9) and B (10) were isolated from the solid culture of Pyrenophora semeniperda (Brittleb. \& D.B. Adam) Shoemaker, ${ }^{16}$ respectively (Fig. 1B, Table 1). Finally, gliotoxin (11) was isolated from the solid culture of Neosartorya pseudofischeri S. W. Peterson ${ }^{17}$ and 6-hydroxymellein (12) was isolated from the liquid culture of Phoma chenopodiicola Gruyter, Noordel. \& Boerema (Fig. 1B, Table 1). ${ }^{18}$ Metabolites 1-3 were from plant origin, while metabolites 4 -12 were from fungal origin (Table 1).

\subsection{Plant growth and pathogen multiplication}

P. sativum subsp. sativum susceptible cv. Messire was used both for pathogen multiplication and assays. Plants were raised from seeds in pots $(6 \times 6 \times 10 \mathrm{~cm})$ filled with a potting mixture (sand/perlite, 1:1 vol/vol), then were grown under standard conditions of in growth chamber at $20 \pm 2^{\circ} \mathrm{C}$ and $65 \%$ relative humidity under a photoperiod at $14 \mathrm{~h} \mathrm{light} / 10 \mathrm{~h}$ dark with light intensity of $150 \mu \mathrm{mol} \mathrm{m} \mathrm{m}^{-2} \mathrm{~s}^{-1}$ photon flux density 
supplied by high-output white fluorescent tubes. As its condition of biotrophic fungi requires, the pea powdery mildew (E. pisi) isolate CO-01 derived from mildew population collected at Córdoba (southern Spain) was maintained on Messire seedlings under conditions described above. Leaves with heavy sporulation were shaken one day before inoculation of selected accessions for the time course study to ensure a supply of young conidia (Fig. 2).

\subsection{Detached leaves assays}

For histological studies, detached leaves were used so that both inoculation density and incubation conditions were controlled precisely. Susceptible plants of cv. Messire were grown under controlled conditions mentioned above until the fifth leaf stage and then, several fourth-formed leaved were excised and placed, adaxial side up, on $4 \%$ technical agar in Petri dishes as described by Rubiales and Carver. ${ }^{19}$ Cut leaves were arranged in a randomized design with four replicates per treatment, each replicate having four leaves. Metabolites listed in Table 1 were tested at concentration of $10^{-2}, 10^{-3}, 10^{-4}, 0.510^{-4}$ and $0.2510^{-4} \mathrm{M}$. Compounds were dissolved in $\mathrm{MeOH}(5 \%)$ and then brought up to the assay concentration with distilled water. The test solutions $(50 \mu \mathrm{L})$ were applied on the adaxial leaf side. Droplets $(50 \mu \mathrm{L})$ of distilled water and $\mathrm{MeOH}(5 \%)$ were applied as negative controls. Droplets $(50 \mu \mathrm{L})$ of commercial anti-powdery mildew fungicide (Nimrod Quattro® (ADAMA): bupirimate 25\%, is the fungicide 5-butyl-2-ethylamino-6methylpyrimidin-4-yldimethylsulphamate at $0.8 \mathrm{M})$ were applied as positive control $\left(0.2 \mathrm{gL}^{-1}\right)$. The solvent was evaporated in a laminar flow cabinet, and then the Petri dishes were inoculated in a spore settling tower with 50 fresh conidiospores $\mathrm{mm}^{-2}$ (Fig. 2). Twenty-four hours after inoculation (h.a.i.), four leaves per plant, treatment and replicate were used to assess percentage of fungal spore germination, number of hyphae per colony and number of fungal tips per colony. Leaves were fixed by placing the adaxial surface upon filter paper moistened with 1:3 (v/v) glacial acetic acid: absolute ethanol. When the chlorophyll was eliminated, the leaves were transferred to filter paper moistened with tap water (minimum $2 \mathrm{~h}$ ) to soften the tissue and then to filter paper moistened with lactoglycerol (1:1:1 v/v, lactic acid: glycerol: water). Fungal development was examined by light microscopy after staining the fungus with $0.25 \%$ Trypan blue, as 
described by Barilli et al. ${ }^{20}$ On every leaf fixed, germination frequency was assessed by scoring 100 conidiospores for the presence of a germ tube. The size of the colonies was also measured for another 35 randomly selected colonies in terms of number of hyphal tips and number of haustoria produced per colony. In addition, presence of necrosis indicating phytotoxic effect of the metabolites tested was also assessed macroscopically.

The effective concentration for $50 \%$ inhibition $\left(\mathrm{EC}_{50}\right)$ was calculated according to Alexander et al. ${ }^{21}$ using the inhibition rate of the fungal isolate in presence of each compounds. Spore germination for each of the replicate was converted to percent inhibition compared with the untreated control by: 100 - ([percent germination of fungicide-compound] / [mean percent germination of control]). The concentration of compounds that effectively inhibited spore germination by $50 \%$ of the untreated control $\left(\mathrm{EC}_{50}\right)$ was determined by linear interpolation.

\subsection{Whole plant assays}

To simulate the effect of the treatments with metabolites on the pathogen under real conditions, several experiments were carried out on whole young plants of the powdery mildew-susceptible pea cv. Messire under the controlled conditions mentioned in Section 2.2. Plants were arranged in a randomized design with five replicates per treatment, each replicate having three plants. Pea plants were inoculated at the third leaf stage by dusting the whole plants with fresh collected conidiospores of E. pisi. Fungal inoculation has already been described in Section 2.3. Metabolites cavoxin, inuloxin C and sphaeropsidin A were applied in whole plants at two concentrations found to be effective in Section 2.3, with no plant phytotoxicity. In order to study the protective effect of the metabolites, a set of plants was treated 5 days before fungal inoculation (DBI), and another set at the same time as fungal inoculation (0 DBI). In addition, to study the curative effect of the metabolites, a third set of plants was treated 2 days after fungal inoculation (DAI). Metabolites 2, 4 and 7 were suspended in distilled water with $\mathrm{MeOH}(5 \%)$ and then sprayed over the canopy of the seedlings until run-off. For the negative controls, plants were untreated (Control), sprayed with distilled water (Water) and sprayed with distilled water with $\mathrm{MeOH}$ (5\%). The commercial powdery mildew 
fungicide (Bupirimato 25\%, ADAMA) was applied as positive control at its recommended concentration of $0.2 \mathrm{~g} \mathrm{~L}^{-1}$. When the fungus macroscopically appeared, disease severity was assessed daily as $\%$ of the whole plant covered by fungal mycelium, until its growth becomes stabilized. These data were used to calculate the area under the disease progress curve (AUDPC), using the following formula:

$$
\left.\operatorname{AUDPC}=\sum_{i=1}^{k} \frac{1 / 2}{2}(\mathrm{~S} i+\mathrm{S} i+1)(\mathrm{t} i+1-\mathrm{t} i)\right]
$$

where $\mathrm{S} i$ is the fungal severity at assessment date $i$, $i$ is the number of days after the first observation on assessment date $i$ and $k$ is the number of successive observations. Finally, the associated necrosis as plant phytotoxicity was assessed.

\subsection{Statistics}

For statistical analysis, average data were subjected to analysis of variance (ANOVA) to test the effect of each phytotoxins and treatment, after which residual plots were inspected to confirm data conformity to normality. Significant of differences between means was determined by calculating honestly-significantdifference (HSD) to test the differences between treatments for each phytotoxin evaluated. All statistical analyses were performed by R software. ${ }^{22}$

\section{RESULTS AND DISCUSSION}

\subsection{Chemical nature of fungal and plant metabolites tested}

The phytotoxins used for the study belong to different classes of natural compounds as inuloxins A and C and $\alpha$-costic acid (1-3, Fig. 1A) which are a three sesquiterpenoid belonging to germacrenolide, eudesmane and custunolide subgroup, respectively. ${ }^{10}$ Sphaeropsidins A and C (4 and 5, Fig. 1A) are a tetra- and tricyclic pimarane diterpenes, ${ }^{11,12}$ cyclopaldic acid and epi-epoformin (6 and $\mathbf{8}$, Fig. 1B), which are a 
pentasubstituted benzofuranone ${ }^{13}$ and a cyclohexen oxide, ${ }^{15}$ respectively. Cytochalasins A and B (9 and 10, Fig. 1B) are two 24-oxa[14]-cytochalasans, ${ }^{16}$ and cavoxin and 6-hydroxymellein (7 and 12, Fig. 1B) are a chalcone ${ }^{14}$ and a tetra- and a tri-substituted benzoic acid and isocoumarine, ${ }^{18}$ respectively. Finally, gliotoxin (11, Fig. 1B) is a representative member of the epipolythiodioxopiperazine (ETP) class, which is well known for its potent cytotoxicity toward cancer cell lines. ${ }^{23}$

Many of these metabolites are isolated as phytotoxins produced by fungi pathogenic to forest plants (Italian cypress and cork oak) as spaheropsidins A and C, cyclopaldic acid and epi-epoformin (4-6 and 8) but also showing other interesting biological activity. In fact, metabolite $\mathbf{4}$ showed bactericide activity as well as a significant anticancer activity associated with a new mode of action, while $\mathbf{5}$ and $\mathbf{8}$ showed insecticide and antirust activities. Cychalasins A and B and 6-hydroxymellein (9, 10 and 12) were isolated from fungi proposed as mycohercides for the control of noxious weeds such as cheatgrass (Bromus tectorum) and fat hen infesting very important agronomic crops, ${ }^{8}$ while cavoxin was reported as a phytotoxin of a fungus pathogenic for chestnut, ${ }^{14}$ and showed a strong antifungal activity against the causal agents of mold (Aspergillus niger and Penicillium roqueforti) in preserved food. ${ }^{25}$ In addition, it was also formulated in a biofilm (PBS: polybutylene succinate) to improve food packaging. ${ }^{25}$ Inuloxins A and $\mathrm{C}$ and $\alpha$-costic acid (1-3) were isolated from an alleopathic plant showed phytotoxic activity against some parasitic weeds such as broomrapes (Orobanche and Pelipanche, spp.) and dodder (Cuscuta campestris). ${ }^{10}$ Finally gliotoxin (11) has antifungal activity. ${ }^{26}$

\subsection{Inhibition of powdery mildew spore germination}

On the pea-powdery mildew pathosystem studied on detached leaves, the percentage of fungal spore germination was higher than $80 \%$ in all the negative controls (control untreated, water and $\mathrm{MeOH} 5 \%$ ), with no significant differences between them (Table 2). This suggests that either water or methanol at 5\% (necessary to dissolve the metabolites above mentioned in water) did not modify normal spore development and did not exert any fungitoxic activity on the pathogen tested. On the contrary, spore germination lower than $15 \%$ was observed in inoculated leaves treated with the fungicide as positive control, as expected. In 
fact, this chemical is a well-known powdery mildew fungicide that prevents powdery mildew sporulation as well as suppresses new subsequent fungal infections. ${ }^{27}$ Most of the metabolites tested significantly reduced powdery mildew spore germination (Table 2), with large differences between effects of the different compounds. Metabolites 1, 2 and $\mathbf{3}$ were effective in reducing spore germination, with an effect that was dose dependent (Table 2). Both metabolites 1 and $\mathbf{2}$ are well known for their seed germination inhibition of parasitic weeds as Orobanche crenata Forssk. and Cuscuta campestris Yunck, ${ }^{10}$ while metabolite 3 showed antimicrobial activity against Pennicillium roqueforti Thom. and Aspergillus niger P.E.L. van Tieghem. ${ }^{28}$ On E. pisi, metabolite 2 was particularly effective when applied at concentrations higher than $10^{-3} \mathrm{M}$, with a reduction on spore germination comparable to the fungicide. Metabolites 3, 4 and $\mathbf{6}$ showed lower antifungal activity, although still significant. Metabolite 5 was less effective, with only some slight but significant inhibition on germination at $10^{-2} \mathrm{M}$. Metabolite 7 reduced spore germination at all concentrations, reaching reductions similar to the fungicide when applied at $10^{-2} \mathrm{M}$ (Table 2), confirming previous results on plant pathogenic fungi as rusts, ${ }^{29}$ Colletotrichum and Phomopsis. ${ }^{30}$ Effects on E. pisi spore germination by metabolites $\mathbf{8}$ to $\mathbf{1 2}$ were moderate to low, not comparable to the fungicide at any concentration.

The effective concentration for 50\% inhibition (EC50) was calculated to compare the fungal sensitivity to the twelve natural compounds and the chemical on the basis of the spore germination inhibition (Table 3). The chemical fungicide is a 5-butyl-2-ethylamino-6-methylpyrimidin-4-yldimethylsulphamate belonging to the DMI (De-Methylation Inhibitors) group of ergosterol-biosynthesis-inhibiting (EBI) fungicides, which showed systemic curative and protectant actions. Because DMI fungicides are powerful inhibitors that operates during the early stages of powdery mildew development (Fungicide Resistance Action Committee [FRAC] group 8), an assay based on spore germination is likely to be a better method for determining sensitivity of powdery mildew to natural compounds compared with the synthetic fungicide. The $\mathrm{EC}_{50}$ value for the fungicide was significantly lower (range 0.092-1.458, average $1.03 \mathrm{gL}^{-1}$ ) than those reported for natural metabolites (Table 3). Regarding the natural metabolites tested, differences in sensitivity were found for $E$. pisi to metabolites 2 (range $1.022-2.532$, mean $\mathrm{EC}_{50}=1.86$ ), 4 (range $0.985-2.751$, mean $\mathrm{EC}_{50}=$ 1.78) and 7 (range $1.678-2.548$, mean $\mathrm{EC}_{50}=1.98$ ), which were comparable with the fungicide (Table 2). 


\subsection{Inhibition of powdery mildew colony development}

As observed for spore germination, high number of hyphal tips per colony (values up to 3) and haustoria per colony (up to 2.5) were achieved by the fungus in the untreated negative controls (water and $5 \% \mathrm{MeOH}$ ), with no significant differences between them (Supplementary Table 1). On the contrary, no or strongly reduced colony development was observed in inoculated leaves treated with the positive control, while several compounds strongly inhibited both number of hyphal tips and haustoria per colony (Supplementary Table 1). This is very significant from a fungal control point of view, as the metabolites enhanced a penetration resistance mechanism which mainly inhibits the fungal infection process after the fungus has formed secondary haustoria, resulting in a lower subsequent fungal expansion. In particular, metabolites $\mathbf{2}, 4$ and 7 were the most effective for controlling further steps of E. pisi development, since values lower than 1.5 hyphal tips per colony were observed, even at the lowest concentration applied $\left(0.2510^{-4} \mathrm{M}\right)$ (Supplementary Table 1). The same tendency was observed for haustoria formation, were values were lower than 1 for metabolite 2 when applied at concentration of $10^{-3}$ and $10^{-2} \mathrm{M}$, and for metabolites 4 and 7 at any concentration applied. These results were comparable with those obtained with the chemical at the same concentration. No phytotoxicity was observed $24 \mathrm{~h}$ after innoculation with any metabolite and at any concentrations tested. As a consequence, inuloxin $\mathrm{C}$, sphaeropsidin $\mathrm{A}$ and cavoxin are promising compounds, as their general high efficacy reducing fungal development in the pea-E. pisi pathosystem included in the study under in vitro conditions. Nevertheless, larger time frames between metabolite application and fungal growth measurements need to be taken into account in further assays in order to evaluate their long-lasting efficacy. For these reasons, in planta assays have been performed under controlled conditions.

\subsection{Studies performed "in planta"}

Inuloxin C (2), sphaeropsidin A (4) and cavoxin (7) were also tested in whole-plant studies under controlled conditions. Metabolites were sprayed on pea susceptible plants at the two lowest concentration found to be 
effective under in vitro conditions $\left(10^{-3}\right.$ and $\left.10^{-2} \mathrm{M}\right)$ at three different time points to fungal inoculation. Then, visible disease was macroscopically evaluated. Treatment with metabolites $\mathbf{2 , 4}$ and 7 provided a significant reduction in the percentage of final disease severity (DS\%) (values < 45\%) and AUDPC (values $<288)(\mathrm{P}<0.001)$ at any time of application compared with the negative controls (DS > 90\%; AUDPC > 455) (Table 4), with no significant differences between compounds in each time of application considered. The detailed microscopic study performed in vitro showed that this protection provided by the metabolites acted both before and after fungal penetration to plant leaves. No symptoms of phytotoxicity were observed on plants treated with metabolites 2 or $\mathbf{4}$, confirming previous results of microscopic assessment, while some necrotic spots were observed on leaves treated with metabolite 7 at 5 days before inoculation (DBI). This is not surprising, as some phytotoxic effects on pea plants have been observed in a study conducted against rust fungi. ${ }^{31}$ Authors observed brown lesions on leaves $48 \mathrm{~h}$ after their treatment with cavoxin. This is probably the reason because we did not microscopically find any symptom, as leaves for histological studies were removed earlier in our study ( 24 hours), when the metabolite did not still affect the plant tissues. The protective effect reached with all metabolites significantly improved when they were applied at the same time as fungal inoculation $(0 \mathrm{DBI})$ compared when they were applied 5 DBI $(\mathrm{P}<0.01)$, similarly to the effects of the commercial fungicide (Table 4, Fig. 4, 5, 6). Here we also found that significantly reduced symptoms compared with untreated controls were strongly maintained when all metabolites were applied 2 days after fungal inoculation (2 DAI) (curative effect) (Table 4, Fig. 4, 5, 6). In fact, fungal development measured as diary evaluation of disease severity (DS\%), as well as the AUDPC, were significantly decreased in plants treated with natural compounds compared with the controls (Table 4, Fig. 4, 5 y 6), with a consequent delay in fungal growth and sporulation. In particular, results on plants treated with metabolites 4 and 7 were comparable with those provided by the fungicide (Table 4, Supplementary Fig. 1). A study on the effects at early and late stages (early aborted colonies and/or primarily mycelial growth impairment) of fungal infection should be considered for further study.

A fully compatible reaction not associated with necrosis was observed in all treatments (Supplementary Fig. 1). As a consequence, the observed resistance after treatment with metabolites was 
never complete, as in the case of all experiments performed under controlled conditions, where high inoculum loads were used in situations favoring pathogen development. However, treatment at least at $10^{-3}$ $\mathrm{M}$ with any metabolite tested effectively reduced by $50 \%$ the disease severity, with this reduction being higher when applied at $0 \mathrm{DBI}$ and 2 DAI. This reduction could be attributed to the toxic effect on the fungus, as all of them showed fungistatic activity against the conidiospores. Information on the mode of action is crucial for the successful development and adoption of any control strategy. Such information is critical to optimize application methods and for correct timing of field sprays.

Biotrophic fungi such as powdery mildew are regularly exposed to fungicides, especially when no genetic resistance is available. ${ }^{5}$ When pathogen control focuses on the deployment of cultivars carrying dominant resistance genes, fungicides contribute about equally to genetics in the control of the disease. As a result, resistance to chemicals evolved by fungal isolates has emerged as one of the most complicated issues threatening food security, leading to the application of general integrated disease management strategies such as dose limitation, mixtures and the search for alternative molecules.

In the present study, twelve fungal metabolites from different sources belonging to different classes of natural compounds were tested with general success for their fungitoxic activity against a disease of agronomic importance as pea powdery mildew. In in vitro studies, inuloxin $\mathrm{C}$, sphaeropsidin $\mathrm{A}$ and cavoxin were promising compounds, all reducing the early developmental stages of E. pisi. At concentrations $10^{-3} \mathrm{M}$ and higher the fungal inhibition was comparable with that of positive control. Furthermore, additional studies performed in planta also showed that the compounds, when applied at the same moment of fungal infection $(0 \mathrm{DBI})$ or later (5 DAI), inhibited fungal growth at pre- and post-penetration stages with consequent preventive and curative effects against powdery mildew infection similar to those achieved by positive control. As cavoxin was phytotoxic to pea, this metabolite is unsuitable for further studies. The effect of against other biotrophic fungi has also been previously proven against leguminous and cereal rusts. $^{29}$ In particular, this metabolite was highly effective against two isolates belonging to Puccinia spp. and four isolates belonging to Uromyces spp. Thus, inuloxin C and sphaeropsidin A warrant further attention to gain a better understanding of its biological properties for practical applications in agriculture 
against powdery mildew and other possible pathogens of agronomic interest. It is also important to note that spharopsidin A is produced in good yield $\left(560 \mathrm{mg} \mathrm{L}^{-1}\right)$ from the liquid culture filtrates of $D$. cupressi, and is easily crystallized as white needles $\left(250 \mathrm{mgL}^{-1}\right) .{ }^{11}$ Scale-up of production in large fermenters to produce large amounts of sphaeropsidin A could make the compound economical for use in agricutlture. Similarly, inuloxin C was obtained in dried I. viscosa plants as pure oil $\left(80 \mathrm{mgkg}^{-1}\right) .{ }^{10}$ This is a common Mediterranean basin plant that it is easy to collect, transport and process, reducing that cost of obtaining abundant amounts of inuloxin C.

\section{ASSOCIATED CONTENT}

Additional information may be found in the online version of this article

\section{Notes}

The authors declare no competing financial interest.

\section{ACKNOWLEDGEMENTS}

The authors thanks Prof. Maddau L., Sparapano L. and Dr. Vurro M. from, respectively, University of Sassari, University of Bari and CNR (Italy), to supply culture of D. cupressi, D. quercivora, S. cupressi, $N$. pseudofisheri, P. cava, P. chenopodiicola and P. semeniperda. We also thank Dr. M. Vurro and Mr. Nicola Montemurro to supply Inula viscosa plant. Research was supported by Programme STAR 2017 (M.M.) (UniNa and Compagnia di San Paolo, Italy). Dr. E. Barilli and M.J. González Bernal are also greatly indebted to AGL2017-82907-R project co-financed by FEDER for financial support.

\section{REFERENCES}

1 Smýkal P, Aubert G, Burstin J, Coyne CJ, Ellis NTH, Flavell AJ, Ford R, Hýbl M, Macas J, Neumann P, Mcphee KE, Redden RJ, Rubiales D, Weller JL and Warkentin TD, Pea (Pisum sativum L.) in the Genomic Era. Agronomy 2:74-115 (2012). 
2 FAOSTAT. Food and Agriculture Organization Corporate Statistical Database. http://faostat.fao.org. (accessed 20 December 2017).

3 Kraft JM and Pfleger FL, Compendium of Pea Diseases and Pests. American Phytopathological Society Press, St. Paul, MN, USA, pp. 14-17 (2001).

4 Iglesias-García R, Rubiales D and Fondevilla S, Penetration resistance to Erysiphe pisi in pea mediated by erl gene is associated with protein cross-linking but not with callose apposition or hypersensitive response. Euphytica 201:381-387 (2015).

5 Fondevilla S and Rubiales D, Powdery mildew control in Pea. A review. Agron Sustain Devel 32: 401-409 (2012).

6 Cimmino A, Andolfi A, Avolio F, Ali A, Tabanca N, Khan IA and Evidente A, Cyclopaldic acid, seiridin, and sphaeropsidin $\mathrm{A}$ as fungal phytotoxin, and larvicidal and biting deterrents against Aedes aegypti (Diptera: Culicidae): structure-activity relationships. Chem Biodiver 10: 1239-1251 (2013).

7 Cimmino A, Andolfi A and Evidente A, Phytotoxic terpenes produced by phytopathogenic fungi and allelopathic plants. Nat Prod Commun 9: 401-408 (2014).

8 Cimmino A, Masi M, Evidente M, Superchi S and Evidente A, Fungal phytotoxins with potential herbicidal acivity: chemical and biological characterization. Nat Prod Rep 32: 1629-1653 (2015).

9 Wang W, Ben-Daniel $\mathrm{BH}$ and Cohen $\mathrm{Y}$, Control of plant diseases by extracts of Inula viscosa. Phytopathology 94: 1042-1047 (2004).

10 Andolfi A, Zermane N, Cimmino A, Avolio F, Boari A, Vurro M and Evidente A, Inuloxins A-D, phytotoxic bi-and tri-cyclic sesquiterpene lactones produced by Inula viscosa: potential for broomrapes and field dodder management. Phytochemistry 86: 112-120 (2013).

11 Evidente A, Sparapano L, Motta A, Giordano F, Fierro O and Frisullo S, A phytotoxic pimarane diterpene of Sphaeropsis sapinea f. sp. cupressi, the pathogen of a canker of cypress. Phytochemistry $\mathbf{4 2}$ : 1541-1546 (1996). 
12 Evidente A, Sparapano L, Fierro O, Bruno G, Giordano F and Motta A, Sphaeropsidins B and C, phytotoxic pimarane diterpenes from Sphaeropsis sapinea f. sp. cupressi and Diplodia mutila. Phytochemistry 45: 705-713 (1997).

13 Graniti A, Sparapano L and Evidente A, Cyclopaldic acid, a major phytotoxic metabolite of Seiridium cupressi, the pathogen of a canker disease of cypress. Plant Pathol 41: 563-568 (1992).

14 Evidente A, Randazzo G, Iacobellis NS and Bottalico A, Structure of cavoxin, a new phytotoxin from Phoma cava and cavoxone, its related chroman-4-one. J Nat Prod 48: 916-923 (1985).

15 Andolfi A, Maddau L, Basso S, Linaldeddu BT, Cimmino A, Scanu B, Deidda A, Tuzi A and Evidente A, Diplopimarane, a 20-nor-ent-pimarane produced by the oak pathogen Diplodia quercivora. J Nat Prod 77: 2352-2360 (2014).

16 Evidente A, Andolfi A, Vurro M, Zonno MC and Motta A, Cytochalasins Z1, Z2 and Z3, three 24-oxa [14] cytochalasans produced by Pyrenophora semeniperda. Phytochemistry 60: 45-53 (2002).

17 Masi M, Andolfi A, Mathieu V, Boari A, Cimmino A, Moreno Y Banuls L, Vurro M, Kornienko A, Kiss $\mathrm{R}$ and Evidente A, Fischerindoline, a pyrroloindole sesquiterpenoid isolated from Neosartorya pseudofischeri, with in vitro growth inhibitory activity in human cancer cell lines. Tetrahedron 69: 74667470 (2013).

18 Cimmino A, Andolfi A, Zonno MC, Berestetskyi A, Vurro M and Evidente A, Chenopodolans A-C: Phytotoxic furopyrans produced by Phoma chenopodiicola, a fungal pathogen of Chenopodium album. Phytochemistry 96: 208-213 (2013).

19 Rubiales D and Carver TLW, Defence reactions of Hordeum chilense accessions to three formae speciales of cereal powdery mildew fungi. Can J Bot 78: 1561-1570 (2000).

20 Barilli E, Rubiales D, Gjetting T and Lyngkjaer MF, Differential gene transcript accumulation in peas in response to powdery mildew (Erysiphe pisi) attack. Euphytica 198: 13-28 (2014).

21 Alexander B, Browse DJ, Reading SJ and Benjamin IS, A simple and accurate mathematical method for calculation of the $\mathrm{EC}_{50}$. J Pharmacol Toxicol Meth 41: 55-58 (1999). 
22 R Development Core Team. R: A Language and Environment for Statistical Computing. R Foundation for Statistical Computing, Vienna (2016).

23 Sun Y, Takada K, Takemoto Y, Yoshida M, Nogi Y, Okada and Matsunaga S, Gliotoxin analogues from a marine-derived fungus, Penicillium sp., and their cytotoxic and histone methyltransferase inhibitory activities. J Nat Prod 75: 11-114 (2011).

24 Masi M, Maddau, L, Linaldeddu BT, Scanu B, Evidente A and Cimmino A, Bioactive metabolites from pathogenic and endophytic fungi of forest trees. Curr Med Chem 25: 208-252 (2018).

25 Santagata G, Valerio, F, Cimmino A, Dal Poggetto G, Masi M, Di Biase M, Malinconico M, Lavermicocca $\mathrm{P}$ and Evidente A, Chemico-physical and antifungal properties of poly (butylene succinate)/cavoxin blend: Study of a novel bioactive polymeric based system. Eur Polymer J 94: 230-247 (2017).

26 Kaouadji M, Steiman R, Seigle-Murandi F, Krivobok S and Sage, L, Gliotoxin: Uncommon ${ }^{1} \mathrm{H}$ couplings and revised ${ }^{1} \mathrm{H}$-and ${ }^{13} \mathrm{C}-\mathrm{NMR}$ assignments. J Nat Prod 53: 717-719 (1990).

27 Bellón-Gómez D, Vela-Corcía D, Pérez-García A and Torésa JA, Sensitivity of Podosphaera xanthii populations to anti-powdery-mildew fungicides in Spain. Pest Manag Sci 71: 1407-1413 (2015).

28 Valerio F, Masi M, Cimmino A, Moeini SA, Lavermicocca P and Evidente A, Antimould microbial and plant metabolites with potential use in intelligent food packaging. Nat Prod Res 32: 1605-1610 (2018).

29 Barilli E, Cimmino A, Masi M, Evidente M, Rubiales D and Evidente A, Inhibition of spore germination and appressoria formation of rust species by plant and fungal metabolites. Nat Prod Commun 11: 1343-1347 (2016).

30 Schrader KK, Andolfi A, Cantrell, CL, Cimmino A, Duke, SO, Osbrink W, Wedge DE and Evidente A, A survey of phytotoxic microbial and plant metabolites as potential products for pest management. Chem Biodivers 7: 221-2280 (2010).

31 Barilli E, Cimmino A, Masi M, Evidente M, Rubiales D and Evidente A, Inhibition of early development stages of rust fungi by the two fungal metabolites cyclopaldic acid and epi-epoformin. Pest Manag Sci 73: 1161-1168 (2017). 
Table 1 Metabolites and controls tested for pea powdery mildew inhibition.

\begin{tabular}{|c|c|c|c|}
\hline Compound & Name & Source & $\begin{array}{l}\text { Molecular } \\
\text { weight }\end{array}$ \\
\hline Control & Water & Water & \\
\hline Control & Water and metanol 5\% & Methanol 5\% & \\
\hline Fungicide & Nimrod Quattro® (ADAMA) & $\begin{array}{l}\text { Bupirimate } 25 \% \text { (p:v) (5-butyl-2-ethylamino-6- } \\
\text { methylpyrimidin-4-yldimethylsulphamate at } 0.8 \mathrm{M} \text { ) }\end{array}$ & \\
\hline 1 & Inuloxin A & Inula viscosa (plant) & 248 \\
\hline 2 & Inuloxin $\mathrm{C}$ & Inula viscosa (plant) & 248 \\
\hline 3 & $\alpha-C o s t i c$ acid & Inula viscosa (plant) & 234 \\
\hline 4 & Sphaeropsidin A & Diplodia cupressi (fungus) & 348 \\
\hline 5 & Sphaeropsidin C & Diplodia cupressi (fungus) & 332 \\
\hline 6 & Cyclopaldic acid & Seridiun cupressi (fungus) & 238 \\
\hline 7 & Cavoxin & Phoma cava (fungus) & 320 \\
\hline 8 & epi-Epoformin & Diplodia quercivora (fungus) & 154 \\
\hline 9 & Cytochalasin A & Pyrenophora semeniperda (fungus) & 477 \\
\hline 10 & Cytochalasin B & Pyrenophora semeniperda (fungus) & 479 \\
\hline 11 & Gliotoxin & Neosartoria pseudofisheri (fungus) & 326 \\
\hline 12 & 6-Hydroxy-mellein & Phoma chenopodicola (fungus) & 194 \\
\hline
\end{tabular}


Table 2 Percentage of spore germination achieved by twelve metabolites at different concentrations $(0.25$ $10^{-4}, 0.510^{-4}, 10^{-4}, 10^{-3}$ and $\left.10^{-2} \mathrm{M}\right)$ tested on pea detached leaves inoculated with powdery mildew. Experiment was performed at 24 hours after inoculation (hai). Values, per column and treatment, followed by different letters differ significantly at $P=0.05$.

\begin{tabular}{|c|c|c|c|c|c|c|c|c|c|c|c|}
\hline \multirow[b]{2}{*}{ Treatment } & \multicolumn{5}{|c|}{ Metabolite 1: Inuloxin A } & \multirow[b]{2}{*}{ Treatment } & \multicolumn{5}{|c|}{ Metabolite 2: Inuloxin C } \\
\hline & $0.2510^{-4} \mathrm{M}$ & $0.510^{-4} \mathrm{M}$ & $10^{-4} \mathrm{M}$ & $10^{-3} \mathrm{M}$ & $10^{-2} \mathrm{M}$ & & $0.2510^{-4} \mathrm{M}$ & $0.510^{-4} \mathrm{M}$ & $10^{-4} \mathrm{M}$ & $10^{-3} \mathrm{M}$ & $10^{-2} \mathrm{M}$ \\
\hline Negative control & $100 \mathrm{a}$ & $100 \mathrm{a}$ & $100 \mathrm{a}$ & $100 \mathrm{a}$ & $100 \mathrm{a}$ & Negative control & $100 \mathrm{a}$ & $100 \mathrm{a}$ & $100 \mathrm{a}$ & $100 \mathrm{a}$ & $100 \mathrm{a}$ \\
\hline Water & $95.3 \mathrm{a}$ & $89.2 \mathrm{a}$ & $87.8 \mathrm{a}$ & $94.5 \mathrm{a}$ & $95.4 \mathrm{a}$ & Water & $95.7 \mathrm{a}$ & $91.6 \mathrm{ab}$ & $93.5 \mathrm{a}$ & $92.3 \mathrm{a}$ & $98 \mathrm{a}$ \\
\hline $\mathrm{MeOH}$ & $95.7 \mathrm{a}$ & $91.2 \mathrm{a}$ & $86.7 \mathrm{a}$ & $88.7 \mathrm{a}$ & $89.9 \mathrm{a}$ & $\mathrm{MeOH}$ & $95.8 \mathrm{a}$ & $88.9 \mathrm{ab}$ & $88.2 \mathrm{ab}$ & $91.6 \mathrm{a}$ & $95.5 \mathrm{a}$ \\
\hline Phytotoxin & $63.9 \mathrm{~b}$ & $47.9 \mathrm{~b}$ & $59.5 \mathrm{~b}$ & $59.2 \mathrm{~b}$ & $53.6 \mathrm{~b}$ & Phytotoxin & $84.4 \mathrm{a}$ & $70.9 \mathrm{~b}$ & $65.2 \mathrm{~b}$ & $28 \mathrm{bc}$ & $25.9 \mathrm{bc}$ \\
\hline \multirow[t]{2}{*}{ Positive control } & $11.7 \mathrm{c}$ & $11.5 \mathrm{c}$ & $9.9 \mathrm{c}$ & $14.4 \mathrm{c}$ & $12.8 \mathrm{c}$ & Positive control & $16.2 \mathrm{~b}$ & $9.0 \mathrm{c}$ & $11.9 \mathrm{c}$ & $10.7 \mathrm{c}$ & $12 \mathrm{c}$ \\
\hline & \multicolumn{5}{|c|}{ Metabolite 3: $\boldsymbol{\alpha}$-Costic acid } & & \multicolumn{5}{|c|}{ Metabolite 4: Sphaeropsidin A } \\
\hline Treatment & $0.2510^{-4} \mathrm{M}$ & $0.510^{-4} \mathrm{M}$ & $10^{-4} \mathrm{M}$ & $10^{-3} \mathrm{M}$ & $10^{-2} \mathrm{M}$ & Treatment & $0.2510^{-4} \mathrm{M}$ & $0.510^{-4} \mathrm{M}$ & $10^{-4} \mathrm{M}$ & $10^{-3} \mathrm{M}$ & $10^{-2} \mathrm{M}$ \\
\hline Negative control & $100 \mathrm{a}$ & $100 \mathrm{a}$ & $100 \mathrm{a}$ & $100 \mathrm{a}$ & $100 \mathrm{a}$ & Negative control & $100 \mathrm{a}$ & $100 \mathrm{a}$ & $100 \mathrm{a}$ & $100 \mathrm{a}$ & $100 \mathrm{a}$ \\
\hline Water & $96.2 \mathrm{a}$ & $90.1 \mathrm{a}$ & $97.5 \mathrm{ab}$ & $97.8 \mathrm{a}$ & $96.5 \mathrm{a}$ & & 9. & 89 & $87.8 \mathrm{a}$ & & $4 \mathrm{a}$ \\
\hline $\mathrm{MeOH}$ & $91 \mathrm{ab}$ & $85.7 \mathrm{ab}$ & $91.6 \mathrm{ab}$ & $97 \mathrm{a}$ & $95.3 \mathrm{a}$ & $\mathrm{MeOH}$ & $95.7 \mathrm{a}$ & $91.2 \mathrm{a}$ & $86.7 \mathrm{a}$ & $88.7 \mathrm{a}$ & $89.9 \mathrm{a}$ \\
\hline Phytotoxin & $82.5 b$ & $72.3 b$ & $70.9 \mathrm{~b}$ & $72.1 \mathrm{~b}$ & $61.2 \mathrm{~b}$ & Phytotoxin & $63.9 b$ & $47.9 \mathrm{~b}$ & $48.5 \mathrm{~b}$ & $43.9 \mathrm{~b}$ & $31.3 b$ \\
\hline \multirow[t]{2}{*}{ Positive control } & $10 \mathrm{c}$ & $14 \mathrm{c}$ & $12.3 \mathrm{c}$ & $10.7 \mathrm{c}$ & $14 \mathrm{c}$ & Positive control & $11.7 \mathrm{c}$ & $12.7 \mathrm{c}$ & $9.9 \mathrm{c}$ & $14.4 \mathrm{c}$ & $16.8 \mathrm{c}$ \\
\hline & \multicolumn{5}{|c|}{ Metabolite 5: Sphaeropsidin C } & & \multicolumn{5}{|c|}{ Metabolite 6: Cyclopaldic acid } \\
\hline Treatment & $0.2510^{-4} \mathrm{M}$ & $0.510^{-4} \mathrm{M}$ & $10^{-4} \mathrm{M}$ & $10^{-3} \mathrm{M}$ & $10^{-2} \mathrm{M}$ & Treatment & $0.2510^{-4} \mathrm{M}$ & $0.510^{-4} \mathrm{M}$ & $10^{-4} \mathrm{M}$ & ${ }^{-3} \mathbf{M}$ & $10^{-2} \mathrm{M}$ \\
\hline Negative & $100 \mathrm{a}$ & $100 \mathrm{a}$ & $100 \mathrm{a}$ & $100 \mathrm{a}$ & 10 & ontrol & 11 & 10 & $100 \mathrm{a}$ & $\mathrm{a}$ & Da \\
\hline Water & $96.8 \mathrm{a}$ & $98.3 \mathrm{a}$ & $96 a$ & $94.6 \mathrm{a}$ & $93.5 \mathrm{a}$ & Water & $88.3 \mathrm{a}$ & $89.3 \mathrm{ab}$ & $88.7 \mathrm{a}$ & $98.3 \mathrm{a}$ & $97.2 \mathrm{a}$ \\
\hline $\mathrm{MeOH}$ & $93.1 \mathrm{a}$ & $89.5 \mathrm{a}$ & $95.6 \mathrm{a}$ & $96.6 \mathrm{a}$ & $96.2 \mathrm{a}$ & $\mathrm{MeOH}$ & 90 & $93 \mathrm{ab}$ & $88 \mathrm{a}$ & $85 \mathrm{ab}$ & $92 \mathrm{a}$ \\
\hline Phytotoxin & $85.2 \mathrm{a}$ & $89.2 \mathrm{a}$ & $91.9 \mathrm{a}$ & $92.2 \mathrm{a}$ & $74.9 \mathrm{~b}$ & Phytotoxin & $56.5 \mathrm{~b}$ & & $52.7 \mathrm{~b}$ & $55.7 \mathrm{~b}$ & $72 b$ \\
\hline \multirow[t]{2}{*}{ Positive control } & $15.3 \mathrm{~b}$ & $15 \mathrm{~b}$ & $14 \mathrm{~b}$ & $8.3 \mathrm{~b}$ & 4.7 & Posit & $13 \mathrm{~b}$ & $12.7 \mathrm{c}$ & $14 \mathrm{~b}$ & $11 \mathrm{c}$ & $12 \mathrm{c}$ \\
\hline & \multicolumn{5}{|c|}{ Metabolite 7: Cavoxin } & & \multicolumn{5}{|c|}{ Metabolite 8: epi-epoformin } \\
\hline Treatment & $0.2510^{-4} \mathrm{M}$ & $0.510^{-4} \mathrm{M}$ & $10^{-4} \mathrm{M}$ & $10^{-3} \mathrm{M}$ & $10^{-2} M$ & Treatment & $0.2510^{-4} \mathrm{M}$ & $0.510^{-4} \mathrm{M}$ & $10^{-4} \mathrm{M}$ & $10^{-3} \mathrm{M}$ & $10^{-2} \mathrm{M}$ \\
\hline Negative control & $100 \mathrm{a}$ & $100 \mathrm{a}$ & $100 \mathrm{a}$ & $100 \mathrm{a}$ & 10 & Negative & 10 & 10 & $100 \mathrm{a}$ & $100 \mathrm{a}$ & $100 \mathrm{a}$ \\
\hline Water & $89.3 \mathrm{a}$ & $95.6 \mathrm{a}$ & $91.7 \mathrm{a}$ & $91.6 \mathrm{a}$ & $89.7 \mathrm{a}$ & & 88 & $87.7 \mathrm{ab}$ & $88 \mathrm{ab}$ & $88 \mathrm{a}$ & $92.7 \mathrm{ab}$ \\
\hline$O H$ & $94.3 \mathrm{a}$ & $91.3 \mathrm{ab}$ & $90.4 \mathrm{a}$ & $88.2 \mathrm{a}$ & $89 a$ & $\mathrm{TeOH}$ & 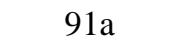 & $87 \mathrm{ab}$ & $85 \mathrm{ab}$ & $85 \mathrm{a}$ & $84.4 \mathrm{~b}$ \\
\hline Phyt & $58.3 \mathrm{~b}$ & 53 & $51.1 \mathrm{~b}$ & $30.6 \mathrm{~b}$ & $21.7 \mathrm{~b}$ & & $78.8 \mathrm{a}$ & & $63.5 \mathrm{~b}$ & $54.2 \mathrm{~b}$ & $86.3 b$ \\
\hline \multirow[t]{2}{*}{ Positive control } & $13 \mathrm{c}$ & $9.3 \mathrm{c}$ & $13.7 \mathrm{c}$ & $14.7 \mathrm{c}$ & $12 \mathrm{~b}$ & Positive control & $11.3 \mathrm{~b}$ & $9.3 \mathrm{c}$ & $15.3 \mathrm{c}$ & $11 \mathrm{c}$ & $9.6 \mathrm{c}$ \\
\hline & \multicolumn{5}{|c|}{ Metabolite 9: Cytochalasin A } & & \multicolumn{5}{|c|}{ Metabolite 10: Cytochalasin B } \\
\hline Treatment & $0.2510^{-4} \mathrm{M}$ & $0.510^{-4} \mathrm{M}$ & $10^{-4} \mathrm{M}$ & $10^{-3} \mathrm{M}$ & $10^{-2} \mathrm{M}$ & Treatment & $0.2510^{-4} \mathrm{M}$ & $0.510^{-4} \mathrm{M}$ & $10^{-4} \mathrm{M}$ & $10^{-3} \mathrm{M}$ & $10^{-2} \mathrm{M}$ \\
\hline Negative control & $100 \mathrm{a}$ & $100 \mathrm{a}$ & $100 \mathrm{a}$ & $100 \mathrm{a}$ & $100 \mathrm{a}$ & Negative control & 10 & 10 & $100 \mathrm{a}$ & $100 \mathrm{a}$ & $100 \mathrm{a}$ \\
\hline Water & $89.3 \mathrm{a}$ & $95.4 \mathrm{ab}$ & $87.7 \mathrm{a}$ & 97.3a & $87.3 \mathrm{a}$ & Water & $90.2 \mathrm{ab}$ & $91.1 \mathrm{ab}$ & $94.7 \mathrm{a}$ & $96.7 \mathrm{ab}$ & $87.5 \mathrm{a}$ \\
\hline & $92.2 \mathrm{a}$ & $88 \mathrm{ab}$ & $89.7 \mathrm{a}$ & $90.7 \mathrm{a}$ & 80 & & $89.3 \mathrm{ab}$ & & $94.7 \mathrm{a}$ & & $90.7 \mathrm{a}$ \\
\hline Phytotoxin & $86 a$ & $76 \mathrm{~b}$ & $77.3 \mathrm{a}$ & $77.7 \mathrm{a}$ & $71.8 \mathrm{~b}$ & Phytotoxin & $72 \mathrm{~b}$ & $73.7 \mathrm{~b}$ & $85.3 \mathrm{a}$ & $81.8 \mathrm{~b}$ & $77.3 \mathrm{a}$ \\
\hline \multirow[t]{3}{*}{ Positive control } & $13.6 \mathrm{~b}$ & $13.4 \mathrm{c}$ & $14.3 \mathrm{~b}$ & $12.1 \mathrm{~b}$ & $10.4 \mathrm{c}$ & Positive control & $15 \mathrm{c}$ & $11 \mathrm{c}$ & $13 \mathrm{~b}$ & $12.4 \mathrm{c}$ & $11.6 \mathrm{~b}$ \\
\hline & \multicolumn{5}{|c|}{ Metabolite 11: Gliotoxin } & & \multicolumn{5}{|c|}{ Metabolite 12: 6-Hydroxymellein } \\
\hline & $0.2510^{-4} \mathrm{M}$ & $0.510^{-4} \mathrm{M}$ & $10^{-4} \mathrm{M}$ & $10^{-3} \mathrm{M}$ & $10^{-2} \mathrm{M}$ & Treatment & $0.2510^{-4} \mathrm{M}$ & $0.510^{-4} \mathrm{M}$ & $10^{-4} \mathrm{M}$ & $10^{-3} \mathrm{M}$ & $10^{-2} \mathrm{M}$ \\
\hline Negative control & $100 \mathrm{a}$ & $100 \mathrm{a}$ & $100 \mathrm{a}$ & $100 \mathrm{a}$ & 10 & Negative control & $100 \mathrm{a}$ & 10 & $100 \mathrm{a}$ & $100 \mathrm{a}$ & $100 \mathrm{a}$ \\
\hline Water & $90 \mathrm{a}$ & & $87.2 \mathrm{a}$ & $95.2 \mathrm{a}$ & 96. & & 95. & & $96.4 \mathrm{a}$ & $90.9 \mathrm{a}$ & $88.9 \mathrm{a}$ \\
\hline $\mathrm{MeOH}$ & $89 \mathrm{ab}$ & $92.8 \mathrm{a}$ & $86.7 \mathrm{ab}$ & $87 \mathrm{ab}$ & $93.5 \mathrm{~b}$ & $\mathrm{MeOH}$ & $91.9 \mathrm{ab}$ & $90.9 \mathrm{a}$ & $82.6 \mathrm{ab}$ & $89.6 \mathrm{a}$ & $88.9 \mathrm{a}$ \\
\hline Phytotoxin & $68 \mathrm{~b}$ & $55.1 \mathrm{~b}$ & $62.6 \mathrm{~b}$ & $68.1 \mathrm{~b}$ & $79.9 \mathrm{~b}$ & Phytotoxin & $78.3 \mathrm{~b}$ & $76.9 \mathrm{a}$ & $66.6 \mathrm{~b}$ & $64.7 \mathrm{~b}$ & $57.7 \mathrm{~b}$ \\
\hline Positive control & $12.3 \mathrm{c}$ & $13.2 \mathrm{c}$ & $14.4 \mathrm{c}$ & $13.8 \mathrm{c}$ & $11.7 \mathrm{c}$ & Positive control & $13 \mathrm{c}$ & $15.66 \mathrm{~b}$ & $13.1 \mathrm{c}$ & $15 \mathrm{c}$ & $12.9 \mathrm{c}$ \\
\hline
\end{tabular}


Table 3 Effective concentration for $50 \%$ inhibition $\left(\mathrm{EC}_{50}\right)$ of different metabolites $\left(\mathrm{gL}^{-1}\right)$ tested on spore growth inhibition of pea powdery mildew. Values followed by different letters differ significantly at $P=$ 0.05 .

\begin{tabular}{lcc}
\hline & \multicolumn{2}{c}{$\mathbf{E C}_{\mathbf{5 0}}$ Spore germination (\%) } \\
\cline { 2 - 3 } \multicolumn{1}{c}{ Compound } & Range & Mean \\
\hline $\mathbf{1}$ & $2.138-4.344$ & $3.52 \mathrm{ab}$ \\
$\mathbf{2}$ & $1.022-2.532$ & $1.86 \mathrm{c}$ \\
$\mathbf{3}$ & $2.253-3.963$ & $3.08 \mathrm{ab}$ \\
$\mathbf{4}$ & $0.985-2.751$ & $1.78 \mathrm{c}$ \\
$\mathbf{5}$ & $2.233-5.001$ & $3.74 \mathrm{ab}$ \\
$\mathbf{6}$ & $2.106-6.702$ & $4.65 \mathrm{a}$ \\
$\mathbf{7}$ & $1.678-2.548$ & $1.98 \mathrm{c}$ \\
$\mathbf{8}$ & $2.683-5.888$ & $4.31 \mathrm{ab}$ \\
$\mathbf{9}$ & $1.957-10.08$ & $4.58 \mathrm{a}$ \\
$\mathbf{1 0}$ & $3.246-5.121$ & $3.94 \mathrm{ab}$ \\
$\mathbf{1 1}$ & $2.402-3.713$ & $3.11 \mathrm{ab}$ \\
$\mathbf{1 2}$ & $2.002-2.762$ & $2.47 \mathrm{bc}$ \\
Positive control & $0.092-1.458$ & $1.03 \mathrm{c}$ \\
\hline
\end{tabular}

Table 4 Disease severity (DS\%) and Area Under the Disease Progress Curve (AUDPC) of Erysiphe pisi development on plants of pea cv. Messire. DS\% is expressed as the percentage of disease severity covering the whole plant 12 days after infection (DAI). Metabolites 2, 4 and 7, negative (untreated, water and $\mathrm{MeOH}$ $5 \%$ ) and positive (bupirimate 25\%) controls were applied to plants at different times to fungal inoculation: 5 days before inoculation (DBI), 0 DBI and 2 days after inoculation (DAI). Compounds were tested at a concentration of $10^{-3}$ and $10^{-2} \mathrm{M}$.

\begin{tabular}{|c|c|c|c|c|c|c|c|}
\hline \multirow[b]{2}{*}{ Time } & \multirow[b]{2}{*}{ Treatment } & \multicolumn{2}{|c|}{ Metabolite 2} & \multicolumn{2}{|c|}{ Metabolite 4} & \multicolumn{2}{|c|}{ Metabolite 7} \\
\hline & & DS\% & AUDPC & DS\% & AUDPC & DS\% & AUDPC \\
\hline \multirow[t]{6}{*}{$5 \mathrm{DBI}$} & Negative control & $95 a$ & $522 a$ & $95 \mathrm{a}$ & $522 \mathrm{a}$ & $96 a$ & $522.5 \mathrm{a}$ \\
\hline & Water & $90 \mathrm{a}$ & $470 \mathrm{a}$ & $90 \mathrm{a}$ & $465 \mathrm{a}$ & $90 \mathrm{a}$ & $465 \mathrm{a}$ \\
\hline & $\mathrm{MeOH} 5 \%$ & $90 \mathrm{a}$ & $535 \mathrm{a}$ & $90 \mathrm{a}$ & $535 \mathrm{a}$ & $90 \mathrm{a}$ & $505 a$ \\
\hline & Positive control & $30 \mathrm{c}$ & $169 \mathrm{c}$ & $28 \mathrm{c}$ & $174 \mathrm{c}$ & $30 \mathrm{c}$ & $171 d$ \\
\hline & $10^{-3} \mathrm{M}$ & $43.3 b$ & $288 b$ & $44 b$ & $249.1 \mathrm{~b}$ & $44.3 \mathrm{~b}$ & $251.6 \mathrm{~b}$ \\
\hline & $10^{-2} \mathrm{M}$ & $35.8 \mathrm{c}$ & $198 \mathrm{c}$ & $35.9 \mathrm{c}$ & $195.6 \mathrm{c}$ & $42.3 b$ & $213.6 \mathrm{c}$ \\
\hline \multirow[t]{6}{*}{0 DBI } & Negative control & $95 a$ & $492.5 \mathrm{a}$ & $95 a$ & $522.5 \mathrm{a}$ & $95 \mathrm{a}$ & $521.5 \mathrm{a}$ \\
\hline & Water & $90 \mathrm{a}$ & $455 \mathrm{a}$ & $90 \mathrm{a}$ & $457 \mathrm{a}$ & $90 \mathrm{a}$ & $455 \mathrm{a}$ \\
\hline & $\mathrm{MeOH} 5 \%$ & $95 a$ & $457 \mathrm{a}$ & $95 a$ & $462 \mathrm{a}$ & $95 \mathrm{a}$ & $467 \mathrm{a}$ \\
\hline & Positive control & Od & $0 \mathrm{c}$ & $0 \mathrm{c}$ & $0 \mathrm{c}$ & $0 \mathrm{c}$ & Od \\
\hline & $10^{-3} \mathrm{M}$ & $30.8 b$ & $115.1 \mathrm{~b}$ & $22.9 \mathrm{~b}$ & $109.9 \mathrm{~b}$ & $29.1 \mathrm{~b}$ & $133.9 \mathrm{~b}$ \\
\hline & $10^{-2} \mathrm{M}$ & $22.2 \mathrm{c}$ & $91.9 b$ & $21 b$ & $91.4 \mathrm{~b}$ & $28.6 \mathrm{~b}$ & $107.9 \mathrm{c}$ \\
\hline \multirow[t]{6}{*}{$2 \mathrm{DAI}$} & Negative control & $90 \mathrm{a}$ & $510 \mathrm{a}$ & $90 \mathrm{a}$ & $510 \mathrm{a}$ & $90 \mathrm{a}$ & $510 \mathrm{a}$ \\
\hline & Water & $90 \mathrm{a}$ & $485 \mathrm{a}$ & $90 \mathrm{a}$ & $485 a$ & $90 \mathrm{a}$ & $485 a$ \\
\hline & $\mathrm{MeOH} 5 \%$ & $90 \mathrm{a}$ & $465 a$ & $90 \mathrm{a}$ & $465 a$ & $90 \mathrm{a}$ & $465 \mathrm{a}$ \\
\hline & Positive control & $0 \mathrm{c}$ & $0 \mathrm{c}$ & $0 \mathrm{~b}$ & $0 \mathrm{~b}$ & $0 \mathrm{c}$ & $\mathrm{Ob}$ \\
\hline & $10^{-3} \mathrm{M}$ & $17 \mathrm{~b}$ & $86.6 \mathrm{~b}$ & $8 b$ & $31.35 \mathrm{~b}$ & $12 b c$ & $54.1 \mathrm{~b}$ \\
\hline & $10^{-2} \mathrm{M}$ & $14.2 \mathrm{~b}$ & $80.9 \mathrm{~b}$ & $7.7 \mathrm{~b}$ & $29.6 \mathrm{~b}$ & $9.4 \mathrm{c}$ & $44.4 \mathrm{~b}$ \\
\hline
\end{tabular}


Fig. 1A Structures of the plant (1-3) and fungal (4 and 5) terpenes tested against pea powdery mildew.<smiles>C=C1C(=O)O[C@H]2C[C@H](C)CCC(=O)/C(C)=C/C[C@@H]12</smiles>

Inuloxin A, 1<smiles>C=C1C(=O)O[C@H]2C[C@@]3(C)C(=C)CCC(C)[C@@]3(O)C[C@@H]12</smiles>

Inuloxin C, 2<smiles>C=C(CC(=O)O)C1CC[C@]2(C)CCC=C(C)[C@@]2(C)C1</smiles>

$\alpha$-Costic acid, 3

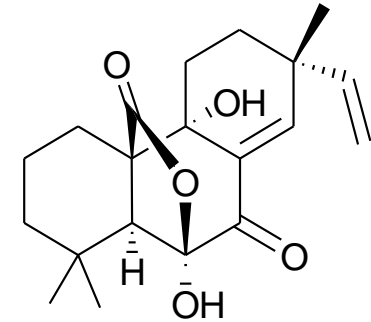

Sphaeropsidin A, 4<smiles>C=C[C@]1(C)C=C2C(=O)C[C@H]3C(C)(C)CCC[C@]3(C(=O)O)C2CC1</smiles>

Sphaeropsidin C, 5

Fig. 1B Structures of the fungal (6-12) metabolites belonging to different classes of natural compounds tested against pea powdery mildew.<smiles>COc1c(C)c(O)c(C=O)c2c1C(=O)O[C@H]2O</smiles>

Cyclopaldic acid, 6<smiles>CCCC=CC=CC(=O)c1c(OC)cc(CO)c(C(=O)O)c1O</smiles>

Cavoxin, 7<smiles>CC1=C[C@@H](O)C2OC2C1=O</smiles>

epi-Epoformin, 8

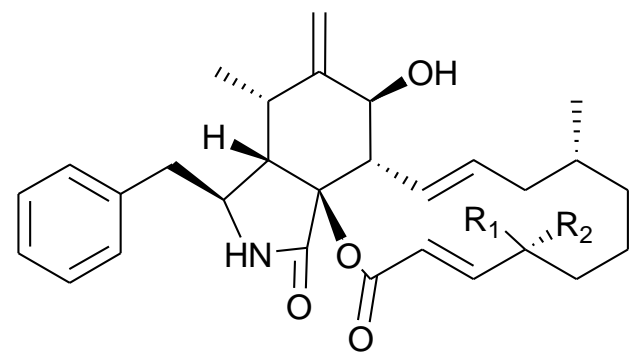

Cytochalasin $\mathrm{B}, \mathbf{9}, \mathrm{R}_{1}=\mathrm{H}, \mathrm{R}_{2}=\mathrm{OH}$ Cytochalasin $A, 10, R_{1}+R_{2}=O$<smiles>C=C1[SH]=C(CO)CN2C1CC1=CC=C[C@H](O)C12</smiles>

Gliotoxin, 11<smiles>C[C@H]1Cc2cc(O)cc(O)c2C(=O)O1</smiles>

6-Hydroxymellein, 12 
Fig. 2 Seedling of Pisum sativum cv. Messire placed in a spore settling tower for E. pisi multiplication (A) and pathogen sporulation eight days after plant inoculation (B). Petri dishes with pea cv. Messire detached leaves treated with phytotoxins at different concentrations (C).

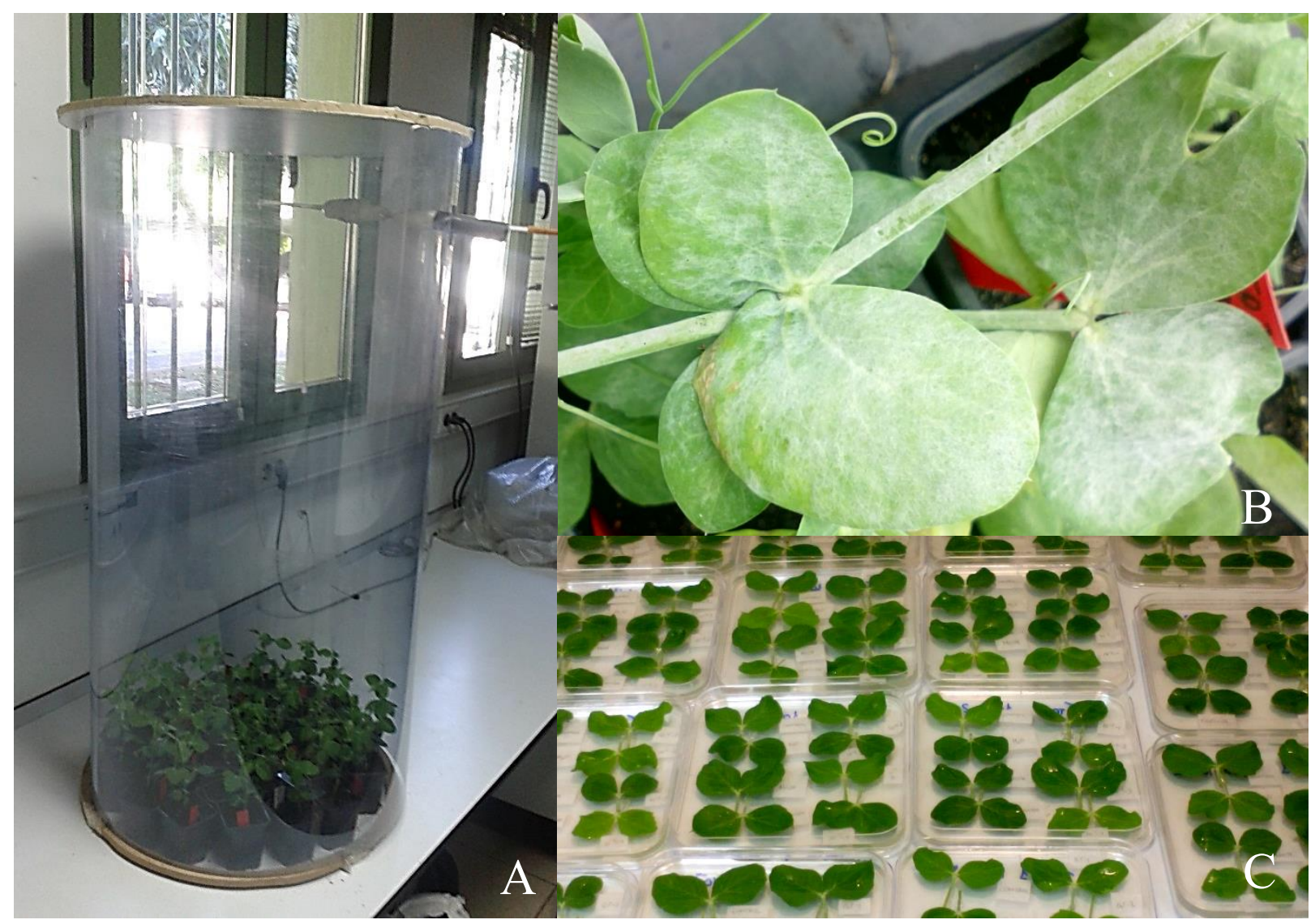


Fig. 3 Diary disease severity (DS\%) development of Erysiphe pisi on plants of pea cv. Messire. DS\% is expressed as the percentage of disease severity covering the whole plant. Metabolites 2, 4 and 7, negative (untreated, water and $\mathrm{MeOH} 5 \%$ ) and positive (fungicide) controls were applied to plants at different times to fungal inoculation: (1) five days before inoculation (5 DBI), (2) 0 DBI and (3) two days after inoculation (2 DAI). Compounds were tested at a concentration of $10^{-3}$ and $10^{-2} \mathrm{M}$.

Time 1: 5 DBI

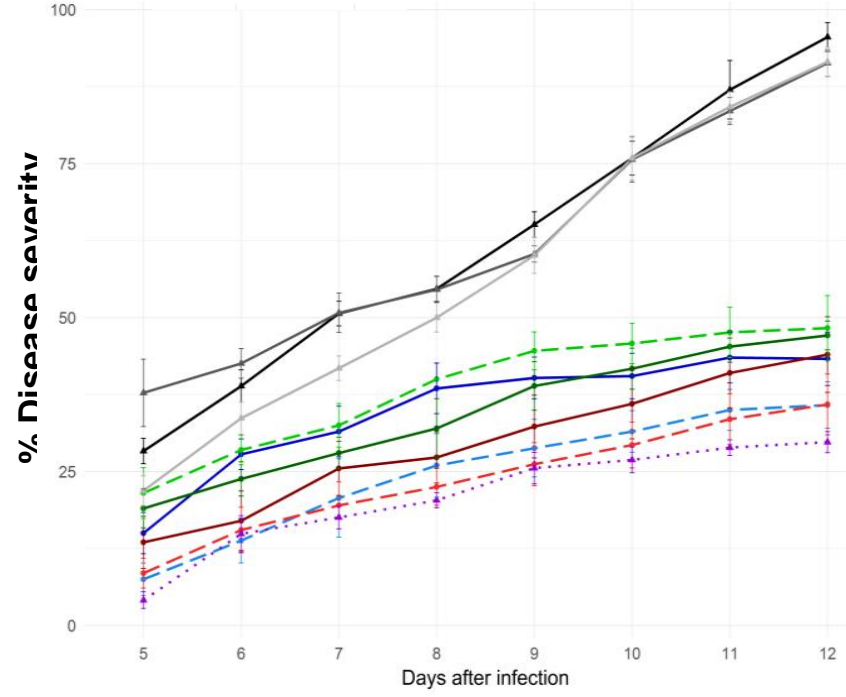

Time 3: 2 DAI

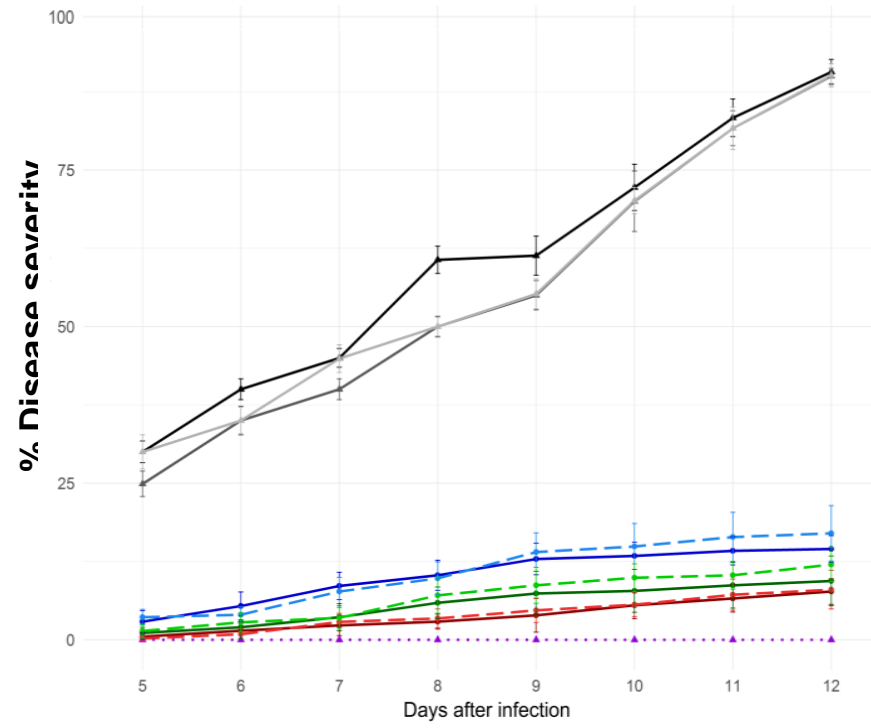

Time 2: 0 DBI

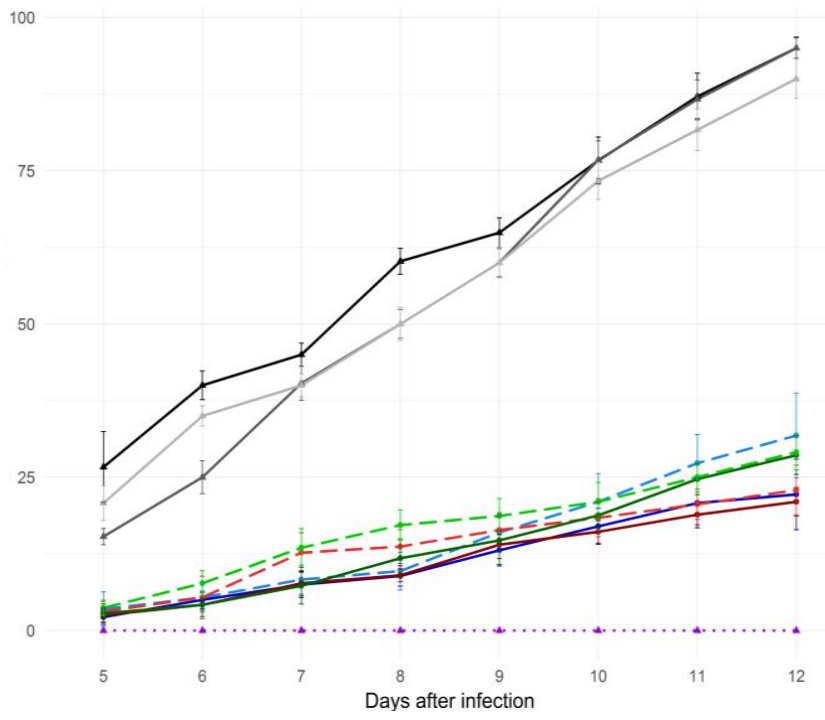

$\rightarrow$ Phytotoxin 2,

$\rightarrow$ Phytotoxin 2,

$\rightarrow$ Phytotoxin 4,

$\rightarrow$ Phytotoxin 4,

$\rightarrow$ Phytotoxin 7,

$\rightarrow$ Phytotoxin 7,

- Cont

^ Funaic

$\perp$ Me

$\simeq$ Wa 
Fig. 4 Powdery mildew symptoms on plants of pea cv. Messire treated with metabolite 2 (Inuloxin) C. Disease Severity (DS\%) is expressed as the percentage of canopy covered by mildew 9 days after infection (DAI). With daily assessments of DS, Area Under the Disease Progress Curve (AUDPC) was calculated. Metabolite 2 (Inuloxin C), negative (untreated, water and $\mathrm{MeOH} 5 \%$ ) and positive (fungicide) controls were applied to plants at different times to fungal inoculation: (1) five days before inoculation (5 DBI), (2) 0 DBI and (3) two days after inoculation (2 DAI). Compounds were tested at a concentration of $10^{-3}$ and $10^{-2} \mathrm{M}$.

\section{Metabolite 2 (Inuloxin C)}
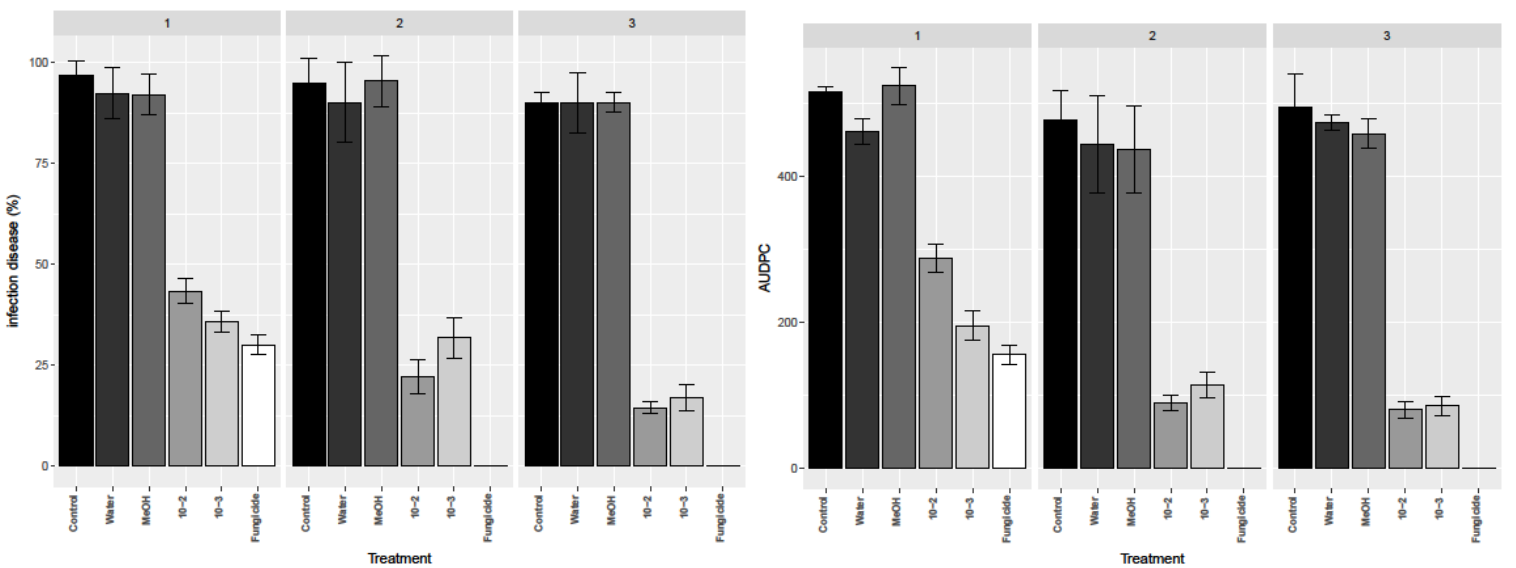
Fig. 5 Powdery mildew symptoms on plants of pea cv. Messire treated with metabolite 4 (Sphaeropsidin A). Disease Severity (DS\%) is expressed as the percentage of canopy covered by mildew 9 days after infection (DAI). With daily assessments of DS, Area Under the Disease Progress Curve (AUDPC) was calculated. Metabolite 4 (Sphaeropsidin A), negative (untreated, water and $\mathrm{MeOH} 5 \%$ ) and positive (fungicide) controls were applied to plants at different times to fungal inoculation: (1) five days before inoculation (5 DBI), (2) 0 DBI and (3) two days after inoculation (2 DAI). Compounds were tested at a concentration of $10^{-3}$ and $10^{-2} \mathrm{M}$.
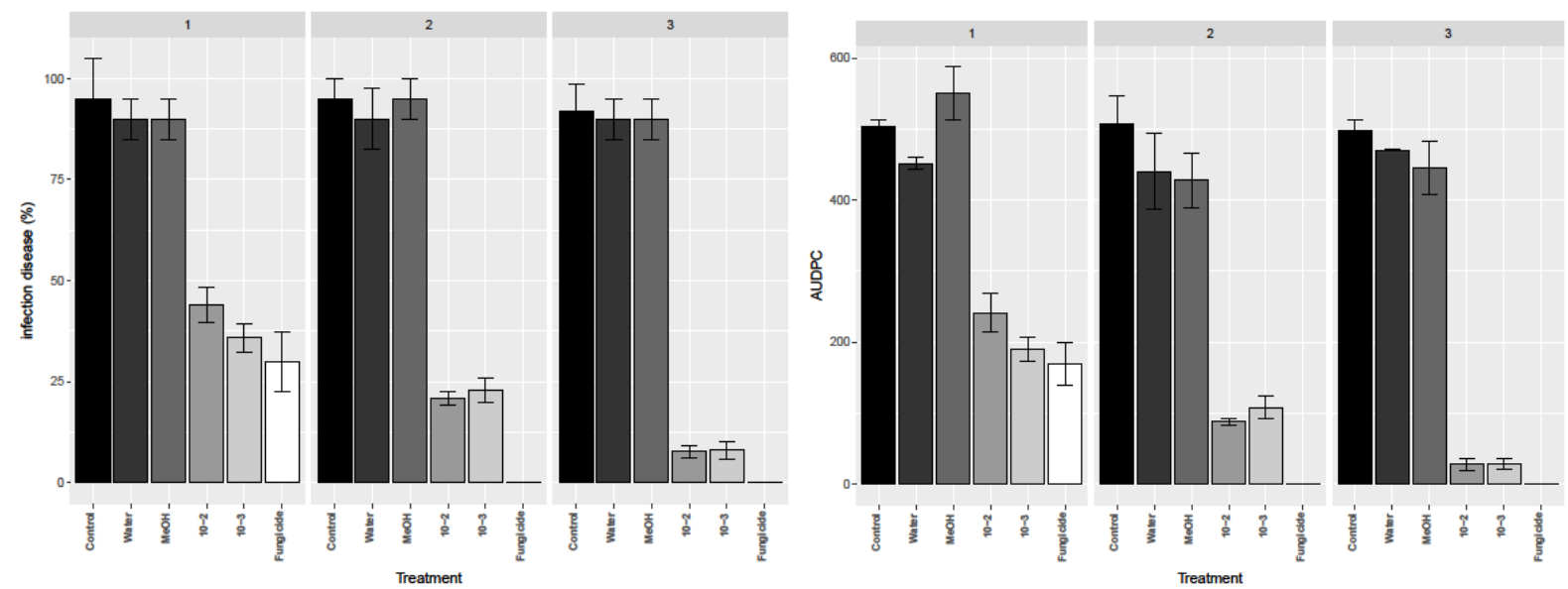
Fig. 6 Powdery mildew symptoms on plants of pea cv. Messire treated with metabolite 7 (Cavoxin). Disease Severity (DS\%) is expressed as the percentage of canopy covered by mildew 9 days after infection (DAI). With daily assessments of DS, Area Under the Disease Progress Curve (AUDPC) was calculated. Metabolite 7 (Cavoxin), negative (untreated, water and $\mathrm{MeOH} 5 \%$ ) and positive (fungicide) controls were applied to plants at different times to fungal inoculation: (1) five days before inoculation (5 DBI), (2) 0 DBI and (3) two days after inoculation (2 DAI). Compounds were tested at a concentration of $10^{-3}$ and $10^{-2} \mathrm{M}$.
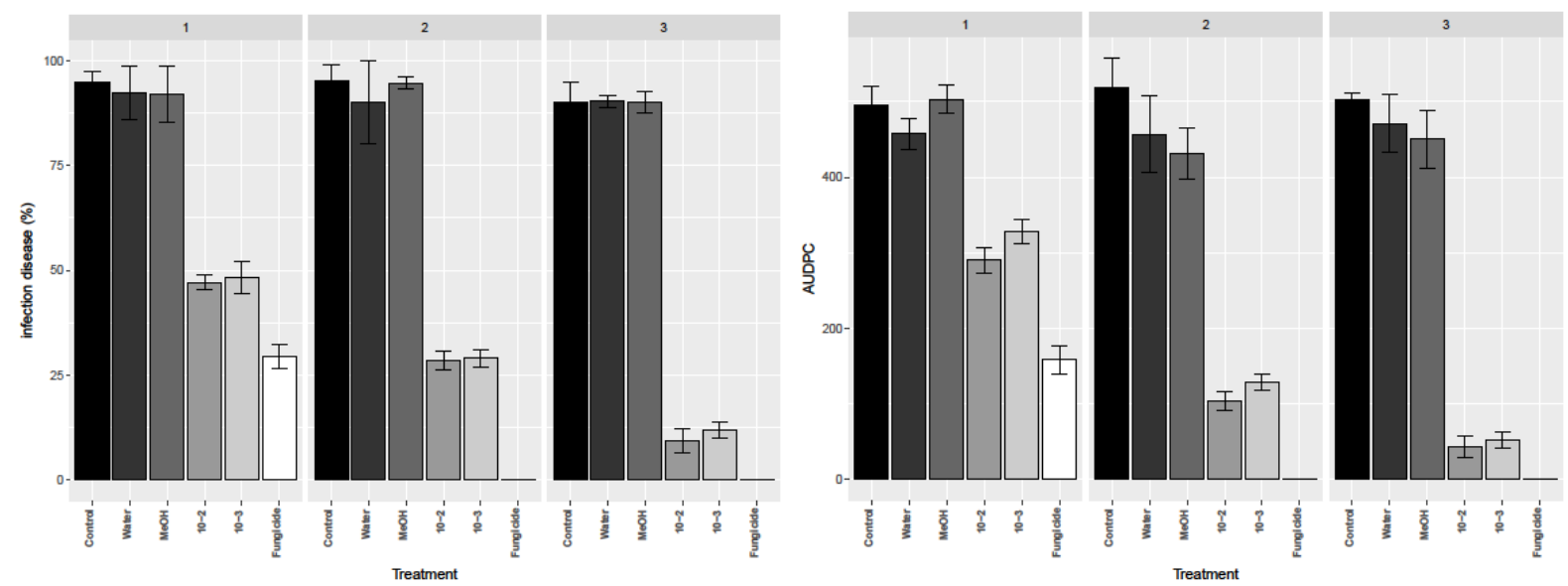


\section{Supplementary Material}

Supplementary Fig. 1 Symptoms of Erysiphe pisi on susceptible pea plants cv. Messire on negative controls (water and $\mathrm{MeOH} 5 \%$ ), positive control (fungicide), and treated with inuloxin $\mathrm{C}$ (2), sphaeropsidin A (4) and cavoxin (7). Disease was scored 9 days after inoculation.

Supplementary Table 1 Effect on Erysiphe pisi hyphal tips development and haustoria formation per colony in Petri dish assays at 24 hours after inoculation (24 h.a.i.) on negative (untreated control, water and $\mathrm{MeOH} 5 \%$ ) controls, treated leaves with inuloxin $\mathrm{C}(2)$, sphaeropsidin A (4) and cavoxin (7) tested at different concentrations $\left(0,25 * 10^{-4}, 0,5 * 10^{-4}, 10^{-4}, 10^{-3}\right.$ and $\left.10^{-2} \mathrm{M}\right)$ and positive control (fungicide Bupirimato 25\%). 